\title{
SIKAP REMAJA PUTRI TERHADAP PERNIKAHAN DINI DI DUSUN WONONTORO DESA JATIAYU KECAMATAN KARANGMOJO KABUPATEN GUNUNGKIDUL
}

\author{
Ekawati ${ }^{1)}$, Kiki Indriyanti ${ }^{2)}$ \\ 1) Program Studi D3 Kebidanan STIKES Jenderal Achmad Yani Yogyakarta \\ 2)Program Studi D3 Kebidanan STIKES Jenderal Achmad Yani Yogyakarta \\ email : ekawati_1412@yahoo.com
}

\begin{abstract}
Background: The phenomenon of early marriage among young people is already very widespread. Special Region of Yogyakarta Ministry of Religious Affairs in 2015 showed that the Gunung Kidul ranked first in early marriage as many as 184 people (0.37\%). According on population and family planning agencies nationwide (BKKBN) in 2014 showed that the high rate of early marriage because of low eduation, economic needs, culture of young marriage and arranged marriage. The purpose to know about the overview of teenage attitudes against early marriage in Wonotoro hamlet, Jatiayu village, Karangmojo, Gunung kidul regency.
\end{abstract}

Methods: Types of quantitative descriptive study, with a total population of 40 respondents. Sampling using total population. Collecting data using questionnaires and closed scales, the percentage univariat data analysis presented in frequency distribution.

Results: The attitude of the young women in the Wonontoro, Jatiayu village shows that teenage girls who supports marriage as much as $45.5 \%$, and that does not support early marriage as much as $57.5 \%$.

Conclusion: The attitude of teenage girl against early marriage in Wonotoro, Jatiayu Village, Karangmojo, Gunung Kidul shows that the majority of teenage girls do not support early marriage as much as 23 respondents $(57,5 \%)$.

Keywords: Teenage girl, attitude, early marriage

\section{PENDAHULUAN}

Pernikahan usia dini adalah pernikahan yang dilakukan remaja pada usia di bawah 16 tahun pada wanita dan di bawah 19 tahun pada pria (Romauli, 2012). Data World Health Organizattion (WHO) tahun 2014 menunjukkan bahwa sebanyak 16 juta kelahiran terjadi pada ibu yang berusia 15-19 tahun atau 11\% dari seluruh kelahiran di dunia yang mayoritas $(95 \%)$ terjadi di negara sedang berkembang. Di Amerika Latin dan Karibia
$29 \%$ wanita muda menikah saat mereka berusia 18 tahun. Prevalensi tertinggi kasus pernikahan usia dini di dunia terdapat di Nigeria (79\%), Kongo (74\%), Afganistan (54\%), dan Bangladesh (51\%). Menurut United Nations Development Economic and Social Affairs (UNDESA 2010 dalam Kemkes 2015), Indonesia merupakan negara ke-37 dengan prosentase pernikahan usia muda yang tinggi dan merupakan tertinggi kedua di ASEAN setelah Kamboja. Data Riset Kesehan Dasar (Riskesdas) tahun 
2013 menunjukkan bahwa, proses pertumbuhan masih berlangsung sampai dengan usia 18 tahun, umur menarche termuda terutama umur 6-12 tahun perlu mendapatkan perhatian khusus untuk tidak menikah. Umur pertama menikah pada usia 10-14 tahun di Indonesia sudah cukup tinggi yaitu 4,8\% dan pada usia 1519 tahun yaitu 41,9\%. Bahkan kelahiran lima tahun terakhir sebelum pengamatan ini dilakukan, sudah terjadi pada 0,3 per 1000 perempuan yang berusia 10-14 tahun, dan 53,9 per 1000 perempuan yang berusia 15-19 tahun. Umur pertama menikah pada usia sangat muda (10-14 tahun) cenderung lebih tinggi di pedesaan $(6,2 \%)$, dan pada kelompok perempuan yang tidak bersekolah $(9,5 \%)$, petani/ nelayan/buruh $(6,3 \%)$, serta status ekonomi terendah $(6,0 \%)$.

Di Indonesia, provinsi dengan prosentase perkawinan dini umur 10-14 tahun tertinggi adalah Jawa Tengah $(52,1 \%)$, Kalimantan Selatan (9\%), Jawa Barat (7,5\%), Kalimantan Timur dan Kalimantan Tengah masing-masing (7\%), dan Banten (6,5\%) sedangkan provinsi dengan prosentase kasus perkawinan dini umur 15-19 tahun tertinggi adalah Kalimantan Tengah (52,1\%), Jawa Barat $(50,2 \%)$, Kalimantan Selatan (48,4\%), Bangka Belitung (47,9\%), dan Sulawesi Tengah (46,3\%) (BKKBN, 2014).

Data Kementrian Agama DIY tahun 2015 menunjukkan bahwa, Gunungkidul menduduki peringkat pertama dalam pernikahan di bawah umur dengan rincian 184 orang (42,1\%). Menurut Kementrian Agama Gunungkidul tahun 2015, angka kejadian menikah di bawah umur tertinggi di Kecamatan Karangmojo dengan rincian 12 orang diikuti dengan Kecamatan Ponjong dengan rincian 10 orang. Adapun pada tahun 2013 dan 2014 angka kejadian menikah di bawah umur di Kecamatan Karangmojo tidak masuk dalam kategori tertinggi dengan rincian pada tahun 2013 sejumlah 8 orang dan 2014 sejumlah 5 orang sehingga ada peningkatan yang sangat signifikan antara tahun 2013 sampai 2015. Data Kementrian Agama di Kecamatan Karangmojo pada tahun 2015 menunjukkan bahwa, angka kejadian menikah di bawah umur tertinggi terletak di Desa Jatiayu dengan rincian 8 orang.

Data Badan Kependudukan dan Keluarga Berencana Nasional (2014) menyatakan bahwa, faktor-faktor yang mempengaruhi terjadinya pernikahan dini adalah faktor pendidikan rendah, faktor kebutuhan ekonomi, faktor kultur nikah muda, pernikahan yang diatur serta seks bebas pada remaja. Adapun menurut Wiji (2011), pernikahan dini sering disebabkan oleh faktor individu itu sendiri, keluarga dan masyarakat serta lingkungan tempat individu tersebut tinggal. Secara umum, faktor yang mempengaruhi pernikahan dini antara lain faktor individu itu sendiri seperti seks bebas pada remaja, faktor keluarga seperti kebutuhan ekonomi dan pernikahan yang telah diatur, serta faktor lingkungan tempat individu tersebut tinggal misalnya kultur nikah muda.

Hasil studi pendahuluan yang dilakukan pada tanggal 24 Maret 2016 di Dusun Wonontoro, Desa Jatiayu, Kecamatan Karangmojo, Kabupaten Gunungkidul diperoleh hasil wawancara pada 10 remaja putri, terdapat 8 dari 10 remaja putri mengatakan sudah mengetahui tentang pernikahan dini, dan $40 \%$ dari 8 remaja putri mendukung adanya pernikahan dini dan $60 \%$ dari 8 remaja putri mengatakan tidak mendukung adanya pernikahan dini.

\section{METODE PENELITIAN}

Jenis penelitian ini adalah penelitian deskriptif kuantitatif dengan pendekatan Cross Sectional. Teknik pengambilan sampel dengan total populasi yaitu 40 remaja putri di Dusun Wonontoro, Desa jatiayu, Kecamatan Karangmojo, Kabupaten Gunungkidul. Dalam penelitian ini menggunakan alat ukur berupa kuesioner dan Skala Likert. Kuesioner yang digunakan adalah kuesioner tertutup, dan skala likert digunakan untuk mengungkap sikap individu dengan uncoring. Skala yang didapat adalah skala hasil adopsi dari penelitian sebelumnya yaitu Rosita (2012). 


\section{HASIL PENELITIAN}

Berdasarkan hasil penelitian dapat diketahui bahwa dari keseluruhan remaja putri, sebagian besar berumur remaja akhir (16-19 tahun) sebanyak 17 responden $(42,5 \%)$ dan status pendidikan saat ini adalah SMP sebanyak 13 responden $(32,5 \%)$ dan SMA sebanyak 13 responden (32,5\%). Selain itu, berdasarkan tabel di atas dapat diketahui bahwa sebagian besar pendidikan orang tua dari responden adalah SD sebanyak 15 responden $(37,5 \%)$ dan pekerjaan dari orang tua responden adalah buruh/tani sebanyak 22 responden $(55,0 \%)$.

Tabel 1.1 Distribusi Frekuensi Sikap

Remaja Putri Terhadap Pernikahan

Dini di Dusun Wonontoro Desa Jatiayu Kecamatan Karangmojo Kabupaten

Gunungkidul.

\begin{tabular}{lcc}
\hline $\begin{array}{l}\text { Sikap remaja putri } \\
\text { terhadap pernikahan } \\
\text { dini }\end{array}$ & F & $\%$ \\
\hline Mendukung & 17 & 42.5 \\
Tidak mendukung & 23 & 57.5 \\
\hline Total & 40 & 100.0 \\
\hline Sumber: Data Primer diolah $(2016)$ &
\end{tabular}

Berdasarkan tabel 1.1 diatas, dapat diketahui bahwa dari 40 responden remaja putri di Dusun Wonontoro Desa Jatiayu Kecamatan Karangmojo Kabupaten Gunungkidul sebagian besar responden memiliki sikap tidak mendukung terhadap pernikahan dini yaitu 23 responden dengan prosentase $57,2 \%$ dan sikap mendukung sebanyak 17 responden dengan prosentase $42,5 \%$.

Berdasarkan hasil penelitian diketahui bahwa dari keseluruhan responden remaja putri di Dusun Wonontoro Desa Jatiayu Kecamatan Karangmojo Kabupaten Gunungkidul sebagian besar remaja berusia antara 1619 tahun dan memiliki sikap tidak mendukung adanya pernikahan dini sebanyak 12 responden (30,0\%). Responden yang berpendidikan SMP sebanyak 7 responden (17,5\%) memiliki sikap tidak mendukung terhadap pernikahan dini dan yang berpendidikan
SMA sebanyak 8 responden $(20,0 \%)$ juga memiliki sikap tidak mendukung terhadap pernikahan dini. Responden yang orang tuanya berpendidikan terakhir SD memiliki sikap tidak mendukung terhadap pernikahan dini sebanyak 9 responden $(22,5 \%)$ dan responden yang orang tuanya bekerja sebagai buruh/tani memiliki sikap tidak mendukung adanya pernikahan dini sebanyak 13 responden $(32,5 \%)$.

\section{PEMBAHASAN}

Hasil penelitian terhadap karakteristik responden berdasarkan umur menunjukkan bahwa sebagian besar remaja putri berusia 16-19 tahun sebanyak 17 orang (42,5\%). Menurut Notoatmodjo (2007), usia seseorang sangatlah berpengaruh dalam memahami setiap informasi yang diberikan semakin tua umur seseorang maka proses perkembangan mentalnya bertambah baik. Hal ini didukung oleh pendapat Wawan dan Dewi (2010) semakin cukup umur, tingkat kematangan dan kekuatan seseorang akan lebih matang dalam berfikir dan bekerja.

Berdasarkan tingkat pendidikan menunjukkan bahwa responden yang berpendidikan SMP sebanyak 7 responden $(17,5 \%)$ dan berpendidikan SMA sebanyak 8 responden (20\%) memiliki sikap tidak mendukung terhadap pernikahan dini. Menurut Ariani (2014), pendidikan merupakan seluruh proses kehidupan yang dimiliki oleh setiap individu berupa interaksi individu dengan lingkungannya baik formal maupun informal yang memberikan perilaku individu maupun kelompok. Sikap remaja putri terhadap pernikahan dini juga dipengaruhi oleh faktor pendidikan, di mana pendidikan adalah suatu upaya untuk memberikan pengetahuan, sehingga terjadi perubahan positif yang mengikat dan kita dapat mawas diri dalam lingkungan kehidupan kita dan semakin tinggi pendidikan kita semakin besar pula tingkat pengetahuan kita (Notoatmodjo, 2007). 
Hasil penelitian ini sesuai dengan penelitian Wijaya dan Ainun (2013), yang menyatakan semakin baik pengetahuan yang dimiliki akan menimbulkan sikap yang baik pada seseorang, responden yang memiliki pengetahuan baik sikap responden cenderung bersikap menolak terhadap pernikahan dini dan responden yang memiliki pengetahuan cukup dan kurang sikap responden cenderung tidak menolak terhadap pernikahan dini.

Pendidikan orang tua responden sebagian besar adalah SD sebanyak 9 responden $(22,5 \%)$ yang memiliki sikap tidak mendukung terhadap pernikahan dini. Menurut pendapat Wawan dan Dewi (2010), tingkat pendidikan seseorang juga akan mempengaruhi sikap orang tersebut. Semakin tinggi tingkat pendidikan seseorang, maka semakin baik pula tingkat pengetahuan yang didapat, dalam hal ini berkaitan dengan sikap yang diajarkan orang tua terhadap anaknya. Pendapat ini juga didukung oleh Notoatmodjo (2007), tingkat pendidikan turut menentukan mudah tidaknya seseorang memahami informasi yang mereka peroleh. Hal ini menunjukkan bahwa informasi yang didapatkan akan berpengaruh pada sikap remaja, apabila informasi yang mereka peroleh benar akan membentuk sikap yang benar pula.

Pekerjaan orang tua responden sebagian besar adalah buruh/tani sebanyak 13 responden (32,5\%) yang memiliki sikap tidak mendukung terhadap pernikahan dini. Menurut pendapat Ariani (2014), pekerjaan adalah suatu kegiatan yang dilakukan seseorang untuk memperoleh penghasilan untuk memperoleh penghasilan guna memenuhi kebutuhan setiap hari. Pekerjaan merupakan faktor yang mempengaruhi tingkat pengetahuan, sehingga seseorang yang bekerja akan memiliki pengetahuan yang lebih luas daripada seseorang yang tidak bekerja, karena dengan bekerja seseorang akan banyak mempunyai informasi dan pengalaman (Wawan dan Dewi, 2010).

Hasil penelitian didapatkan bahwa sikap remaja putri terhadap pernikahan dini berdasarkan aspek kognitif sebagian besar memiliki sikap yang tidak mendukung terhadap pernikahan dini yaitu sebanyak 25 responden (62,5\%) yang terdapat pada remaja yang berusia 16-19 tahun sebanyak 15 responden $(37,5 \%)$. Aspek kognitif merupakan kepercayaan seseorang mengenai apa yang dipercayai oleh individu pemilik sikap dalam menanggapi masalah isu atau problem yang kontroversional (Azwar, 2015).

Hasil penelitian tersebut sesuai dengan penelitian yang dilakukan oleh Kumiadi dan Yuliati (2014), yang menyatakan sebagian remaja putri di Wilayah Kerja Puskesmas Karta Raharja Kabupaten Tulang Bawang pada tahun 2014 mempunyai sikap tidak mendukung terhadap pernikahan dini yaitu $(64,0 \%)$. Hasil ini didukung oleh pendapat Ahmadi (2008), yang menyatakan sikap remaja yang memandang pernikahan dini tidak menimbulkan masalah bagi kesehatan reproduksi menyebabkan remaja cenderung tanpa pertimbangan mengambil keputusan untuk menikah dini yang hanya didasarkan kepada pola pikir dan pandangan bahwa telah saling mencintai dan siap untuk menikah.

Hasil penelitian didapatkan sikap remaja putri terhadap pernikahan dini berdasarkan aspek afektif sebagian besar remaja putri memiliki sikap yang tidak mendukung terhadap pernikahan dini yaitu sebanyak 23 responden $(57,5 \%)$ yang terdapat pada remaja yang berusia 16-19 tahun sebanyak 17 responden (42,5\%). Aspek Afektif merupakan perasaan yang menyangkut aspek emosional. Aspek emosional inilah yang berakar paling dalam sebagai komponen sikap karena secara umum aspek ini disamakan dengan perasaan yang dimiliki seseorang terhadap sesuatu (Azwar, 2015).

Berdasarkan hasil penelitian tersebut menunjukkan bahwa hasil tersebut sesuai dengan penelitian yang dilakukan oleh Tati (2012), yang menyatakan bahwa sebagian besar responden memiliki sikap terhadap pernikahan dini dengan kategori kurang baik yaitu sebanyak 163 responden 
(54,5\%). Hal ini dipengaruhi oleh pengetahuan tentang kesehatan reproduksi yang cukup baik karena informasi yang diperoleh dari berbagai sumber. Selain itu, dalam keseshatan reproduksi juga terdapat informasi mengenai pernikahan yang aman dan resiko kesehatan yang dialami oleh pasangan yang menikah pada usia reproduksi yang belum aman sehingga hal ini dapat mempengaruhi pola pikir remaja dalam menyikapi masalah pernikahan dini.

Hasil penelitian didapatkan hasil bahwa sikap remaja putri terhadap pernikahan dini berdasarkan aspek konatif sebagian remaja putri memiliki sikap tidak mendukung pernikahan dini yaitu sebanyak 22 responden (55,0\%) yang terdapat pada remaja yang berusia 16-19 tahun sebanyak 13 responden $(32,5 \%)$. Aspek konatif merupakan aspek kecenderungan berperilaku tertentu sesuai dengan sikap yang dimiliki seseorang (Azwar, 2015).

Hasil penelitian tersebut sesuai dengan pendapat Ahmadi (2008), yang menyatakan rendahnya status ekonomi keluarga berhubungan dengan keinginan orang tua agar remaja segera menikah sehingga tidak menjadi beban secara finansial bagi keluarga dan dapat hidup dengan mandiri tanpa tergantung dengan orang lain. Menurut peneliti remaja putri yang mendukung terhadap pernikahan dini menganggap bahwa mengurangi beban keluarga adalah alasan utama untuk menikah muda karena setelah menikah akan menjadi tanggung jawab suami.

Hasil yang didapatkan dari keseluruhan penelitian yang telah dilakukan di Dusun Wonontoro Desa Jatiayu Kecamatan Karangmojo Kabupaten Gunungkidul sebagian besar remaja putri memiliki sikap tidak mendukung terhadap pernikahan dini sebanyak 23 responden $(57,5 \%)$ dan sebanyak 17 responden (42,5\%) memiliki sikap mendukung terhadap pernikahan dini. Hasil penelitian ini sesuai dengan penelitian Ayu, Budi dan Erika (2013), yang menyatakan sebagian besar remaja putri MTs Sunan Gunung Jati Katemas Kudus Jombang mempunyai sikap menolak pernikahan dini yaitu $54,1 \%$.

Jika dibandingkan antara kenyataan yang ada di Dusun Wonontoro dengan analisis hasil penelitian yang telah dilakukan, menunjukkan hasil penelitian tidak sesuai dengan kenyataan yang ada di lahan. Hal ini menunjukkan bahwa kemungkinan besar remaja putri dalam melakukan pengisian kuesioner tidak jujur dan dikarenakan juga keterbatasan peneliti dalam melakukan penelitian dimana dalam memilih waktu penelitian kurang tepat.

Asumsi lain yang dapat dijabarkan berdasarkan hasil penelitian adalah ada beberapa faktor yang menyebabkan remaja putri di Dusun Wonontoro masih banyak yang memiliki sikap mendukung terhadap pernikahan dini yaitu sikap dan hubungan remaja putri dengan orang tua di mana rasa patuh dan tidak berani menentang orang tua menjadi faktor utama yang mendasari mereka mendukung terhadap pernikahan dini. Faktor lain yang mempengaruhi sikap remaja putri mendukung pernikahan dini adalah mereka beranggapan bahwa perempuan yang sudah haid wajib untuk menikah, perempuan sebaiknya menikah pada usia < 16 tahun, perempuan tidak perlu berpendidikan tinggi karena harus menikah, menikah usia muda merupakan suatu kebanggan karena merasa cepat laku dan lebih baik menikah pada usia 15 tahun daripada menjadi perawan tua.

Faktor-faktor diatas sesuai dengan pendapat Romauli (2012), tentang faktor penyebab terjadinya pernikahan dini antara lain, tingkat pendidikan seseorang dimana semakin rendahnya tingkat pendidikan seseorang akan mendorong cepatnya pernikahan dini, sikap dan hubungan dengan orang tua di mana anak biasanya patuh terhadap orang tua serta anggapan bahwa pernikahan dini merupakan jalan keluar dari berbagai kesulitan. Faktor lain yang menjadi penyebab pernikahan dini adalah pandangan dan kepercayaan seseorang dimana mereka beranggapan bahwa kedewasaan seseorang dinilai dari status 
perkawinan dan menikah usia muda adalah suatu kebanggaan karena mereka merasa cepat laku. Adapun faktor lain yang berpengaruh yaitu faktor masyarakat di mana lingkungan tempat mereka tinggal beranggapan jika gadis belum menikah dianggap sebagai aib keluarga dan menjadi perawan tua jika belum menikah diusia 15 tahun.

\section{KESIMPULAN}

Sebagian besar remaja putri di Dususn Wonontoro Desa Jatiayu Kecamatan Karangmojo Kabupaten Gunungkidul bersikap tidak mendukung pernikahan dini sebanyak 23 responden dengan prosentase $57,5 \%$. Diharapkan tenaga pelayanan kesehatan lebih aktif dalam menyikapi masalah pernikahan dini dan memberikan penyuluhan tentang pernikahan dini dan dampaknya bagi ibu dan anak sehingga akan menurunkan angka pernikahan dini di Dusun Wonontoro.

\section{DAFTAR PUSTAKA}

Ahmadi, 2008. Psikologi Umum. Jakarta: PT Rineka Cipta.

Ariani, A. 2014. Aplikasi Metodologi Penelitian Kebidanan dan Kesehatan Reproduksi. Yogyakarta: Nuha Medika

Ayu, Budi, dan Erika. 2013. Gambaran Sikap Remaja Putri tentang Perkawinan Dini di MTs Sunan Gunung Jati Katemas Kecamatan Kudus Kabupaten Jombang. Metabolisme. Vol 2, No 4, 1-6. Diakses pada tanggal 29 April 2016 Jam 17.50 WIB.

Azwar, S. 2015. Sikap Manusia, Edisi 2. Yogyakarta: Pustaka Pelajar.

Badan Penelitian dan Pengembangan Kesehatan. 2013. Riset Kesehatan Dasar (Riskesdas 2013). Kementrian Kesehatan Republik Indonesia: Jakarta.
BKKBN. 2014. Pernikahan Dini Pada Beberapa Provinsi di Indonesia. KRR: Jakarta.

Departemen Agama Gunungkidul. 2015. Pernikahan dini <20 Tahun. Gunungkidul: Departemen Agama.

Departemen Agama Yogyakarta. 2015. Pernikahan dini <20 Tahun. Yogyakarta: Departemen Agama.

Kemenkes RI. 2015. Profil Kesehatan Indonesia 2015. Jakarta: Kemenkes RI.

Notoatmodjo, S. 2007. Kesehatan Masyarakat IImu dan Seni. Jakarta: Rineka Medika.

Romauli, S. 2012. Kesehatan Reproduksi. Yogyakarta: Nuha Medika.

Rosita, S. 2012. SKRIPSI: Hubungan Pengetahuan Tentang Dampak Perkawinan Dini Pada Kehamilan dan Persalinan dengan Sikap Remaja Putri Terhadap Perkawinan Dini di SMP Budi Utomo Kecamatan Bandar Huluan Kabupaten Simalungun Tahun 2012. Sumatra Utara: Universitas Sumatra Utara.

Tati, Enung. 2012. SKRIPSI: Hubungan Pengetahuan Remaja Tentang Kesehatan Reproduksi Dengan Sikap Terhadap Pernikahan Dini Di Wilayah Kerja Puskesmas Sukakarya Kota Sukabumi. Sukabumi: STIKES Kota Sukabumi

Wawan, dan Dewi. 2010. Teori Pengukuran Pengetahuan Sikap dan Perilaku Manusia. Yogyakarta: Nuha Medika.

WHO. 2014. The WHO Application of ICD-10 to deaths during pregnancy,childbrith and the puerperium. ICD-MM. http://apps.who.int/iris/bistream/1066 5/70929/1/9789241548458 eng.pdf. Diakses pada tanggal 15 April 2016 Jam 14:30 WIB. 
Widyastuti, Y. 2009. Kesehatan

Reproduksi. Yogyakarta: Fitramaya.

Wiji. 2011. Kesehatan Reproduksi. Jakarta: EGC. 